\title{
The Recovery of England's »skrinlagt fortid« - a progressive Report
}

\author{
By S.A.J. Bradley
}

The following article is based upon a paper delivered at the University of Aarhus in September 1998 in connection with the celebration of the tenth anniversary of the foundation of the Center for GrundtvigStudier. ${ }^{1}$

The skrinlagt fortid of my title comes from a lecture published in 1873 by Frederik Helveg. ${ }^{2}$ What first attracted Grundtvig to England in 1829 , says Helveg, was England's "skrinlagt fortid, det angelsaksiske« England's Anglo-Saxon past, laid away and forgotten in dusty archives. But, Helweg continues, what proved in fact to be at least as important in Grundtvig's development thereafter was what he learnt "gennem det samtidige og samlevende - contemporary English ideas on education, on the church, on personal liberty and so on - during his antiquarian visits to England in 1829, 1830 and 1831. The editors of the Haandbog $i$ N.F.S. Grundtvigs Skrifter draw from the record of his writings a similar evaluation: the England-visits »faar deres Betydning ikke saa meget ved hans Studier af de angelsachsiske Haandskrifter, hvor det bliver Englænderne selv, der høster Frugterne, som ved de frugtbare Tilskyndelser, Livet i England paa mangfoldig Maade giver ham. ${ }^{3}$ Broadly and briefly speaking, this is the account which became set in amber or aspic for a generation or two after Kaj Thaning's highly influential definition of a model of Grundtvig's development over the critical period around $1832 .^{4}$

If I am asked, therefore, what aims the Centre for Grundtvig Studies has had in opening up a review of Grundtvig and Anglo-Saxondom, I would say that one was simply to promote - to an English-speaking as well as to a Danish readership - an awareness of the sheer extent and duration of Grundtvig's commitment to the Anglo-Saxon legacy as found in those manuscripts; to let it be seen that this was a commitment reaching far beyond his work on Beowulf and the composition of the small group of hymns in the Sangvark inspired by Anglo-Saxon themes. ${ }^{5}$ And I might also imply an answer in the form of a question or two about Kaj Thaning's estimation of the significance (or rather, relative insignificance) of the Anglo-Saxon manuscripts. 
A convenient summary of Thaning's authoritative understanding of Grundtvig's development in the 1830s is his own introduction to Grundtvig at the international Grundtvig Seminar of $1972 .{ }^{6}$ There Thaning notes that Grundtvig »cultivated Anglo-Saxon in order to be able to translate medieval Anglo-Saxon poetry. In that particular area he won for himself international recognition. «And Grundtvig went on his three visits to England »in order to study old Anglo-Saxon manuscripts in the English libraries, in which the English themselves were showing no interest. That is the first and last time he mentions the manuscripts and their content. It is admittedly not his brief on this occasion to "go into the sources of his inspiration in England, except to say that they did not have any immediate influence. « But »these travels changed his life and the universe of his thought. Grundtvig became a new man.« Grundtvig now had to »write himself into clarity « says Thaning, quoting Grundtvig. And this he did in his new edition of Nordens Mythologi - a work which Thaning describes as Grundtvig's »decisive breakthrough in the development of his view of the eternal and the worldly life and their relation to each other. «»Now « says Thaning »he could distinguish between the work of the Creator and of the Saviour.« Nothing more, however, about the Anglo-Saxon literature.

Yet Grundtvig transcribed, copied and sometimes recopied over this period many hundreds of lines of Anglo-Saxon poetry from the Exeter Book. It would have been impossible to achieve such accuracy of transcription as he did without understanding the meaning of this poetry; and it is hard to imagine Grundtvig, of all people, understanding such a poetic discourse without also engaging in its sense and judging its topics, ideas, values and forms of expression relative to those he brought with him as his own cultural stock. ${ }^{7}$

So, my questions relative to Thaning's influential thesis are: Is this an informed exclusion - if so, does it not need to be challenged? Or is it an omission explained by imperfect knowledge (of which we all, heaven knows, have our share!) - and if so, does it not need to be remedied by further research?

Frederik Hammerich's well-known anecdote records that in the very last days of his life Grundtvig was not only still acquiring new books on Anglo-Saxon - but going to considerable trouble to read and discuss them with his friends. ${ }^{8}$ But in any case the catalogue of Grundtvig's library at the time of its auction in 1873 confirms that many of the leading editions and studies of Anglo-Saxon literature, published at 
intervals over all these years, were added to his bookshelves; and his annotations in a number of these books indicate that he took them aboard in intellectual and scholarly terms.

I know there are dangers in judging a person by the books on his library shelves. But apart from my own awareness of the parallel testimony afforded by Grundtvig's papers in the Grundtvig Arkiv, I have no less an authority than Helge Toldberg for taking note of the contents of Grundtvig's library. He wrote that: »De bøger, Gr. har ejet eller laant, har haft en langt større indflydelse paa hans forfatterskab end almindeligt antaget. « His own consideration of Grundtvig's books has led him to conclude: »at der med aarene blev nøjere og nøjere sammenhæng mellem Gr.s læsning og forskellige virksomhed. «" So Grundtvig acquired, for example: ${ }^{10}$

- Two copies of Thorpe's 1832 edition of the Oxford Bodleian MS Junius 11 containing the poems once popularly called The Paraphrases of Cadmon; ${ }^{11}$ to which he later added a new edition of the Paraphrases by K.W. Bouterwek. ${ }^{12}$ Interesting because of Grundtvig's remarkable interaction with this corpus of poetry. More about this below.

- Thorpe's edition of the Anglo-Saxon Psalter with Anglo-Saxon paraphrases. ${ }^{13}$ Interesting for those of us concerned with Grundtvig's creative response to the poetic diction of the ancient North. The psalms of David, an absolutely primary model for religious expression in poetry within the literary tradition of western Christendom, were early glossed and paraphrased in English by the Anglo-Saxons and had a discernible influence upon the diction of Anglo-Saxon religious poetry. It should not surprise us therefore that Grundtvig was interested in the ancient 'Northern' vernacular poetic language of the Anglo-Saxon psalms - and annotated Thorpe's edition of them.

- J.M. Kemble's English edition (1843) of the fairly recently discovered codex now called the Vercelli Book - one of the four surviving major codices of Anglo-Saxon poetry. Interesting not least because this codex contains among the rest The Dream of the Rood..$^{14}$ More upon this important connection shortly.

- Thorpe's edition of the Catholic Homilies of Ælfric. ${ }^{15}$ Interesting to those of us concerned with the possibility of influence upon Grundtvig from Anglo-Saxon prose diction, and particularly Anglo-Saxon prosepoetry, such as we find here and there in Elfric's great cycles of homilies for the (western) Church's liturgical year. 
- H.W. Norman's edition of the Anglo-Saxon version of the Hexameron of St. Basil and of St. Basil's Admonitio ad filium spiritualem [Advice to a spiritual son $].{ }^{16}$ Interesting because it reminds us that Grundtvig's exposure to the personalities and thought of the eastern Church and his consciousness of the catholicity of the early Church in the North could well have been enhanced in some degree by those Anglo-Saxon manuscripts of which Thaning and Helweg had little in detail to say.

- And of course, publications of Anglo-Saxon literature and AngloSaxon antiquities by George Stephens, English-born professor in the University of Copenhagen. These include Stephens's recreation of the Old English poem The Phoenix in alliterative verse $;{ }^{17}$ his edition of the two leaves of a lost Anglo-Saxon epic poem on Waldere found in the Royal Library, Copenhagen $;^{18}$ and his great work, The old-northern runic monuments (1866-68). ${ }^{19}$ Interesting not least because of the personality and academic status of Stephens and his friendship with Grundtvig; and because his book on runic monuments contains a fine engraving of the Ruthwell Cross - the great Anglo-Saxon stone cross from about 700 at Ruthwell in Dumfries, Scotland, with lines from a version of The Dream of the Rood carved upon it in runes. These runes, Stephens had persuaded himself, declared Cædmon's authorship of this poem. Interesting also in view of the attention A.M. Allchin has drawn to Grundtvig's »strong devotion to making the sign of the cross « and his household's use of a prayer which »has something of the character of a lorica or breastplate, the kind of prayer for protection from evil through the power of the holy cross, which we find in early Celtic Christianity. $\ll^{20}$ This topic too I shall briefly take up again below, in another Grundtvigian context.

So this glance at Grundtvig's bookshelves conveniently gives both some idea of areas of 'Grundtvig and Anglo-Saxondom' which have been opening up for me at least as I have ventured into Grundtvig over the past few years, and some indication of where further research might bear fruit.

Now what of the published outcome of Grundtvig's studies? The primary works are: the first and second editions of his fordanskning of Beowulf, called Bjowulfs Drape. Et Gothisk Helte-Digt fra forrige AarTusinde af Angel-Saxiske paa Danske Riim ved Nik. Fred. Sev. Grundtvig Praest (Copenhagen, 1820), and significantly re-titled in the second edition (1865) as Bjovulvs Drapen, et Høinordisk Heltedigt, fra Anguls-Tungen fordansket (1865), ${ }^{21}$ his edition of The Phoenix (1840), 
and his edition of Beowulf (1861). Very closely related to the primary texts are the discussions - the polemical discussions - of these texts, both within the editions mentioned and in Grundtvig's related articles in periodical literature and in his lectures.

Grundtvig's published contributions to international Anglo-Saxon scholarship relate primarily to Beowulf. ${ }^{22}$ Here, as Thaning and others have observed, he indeed won international notice. But his PhenixFuglen has commanded little attention outside of Denmark. ${ }^{23}$ This fact reminds us that there was a price to pay, in terms of international acknowledgement, for making so thoroughly Danish a statement out of his edition. The archetypal motif of rebirth there has unconcealed implications for both the domestic political life and aandslivet in Denmark in 1840; the apparatus attached to the edition delivers this Danish polemic; the Danish language used by Grundtvig in preference to anything more international is part of the polemic. And so here is an important issue in the study of Grundtvig and Anglo-Saxondom and in the mission to make his work better known outside Denmark in the late twentieth century. Grundtvig was not uninterested in international recognition: he was indignant when foreign scholars failed to recognise contributions he had made to Anglo-Saxon scholarship; and he rather proudly sent presentation copies of his Beowulf to the British Museum and the Bodleian Library in Oxford, and to Cambridge. But why then did he not use Latin as his editorial language, after Thorkelin's example? Or German like Grein and Ettmüller? Or English, like Thorpe? I won't waste my audience's time by bothering to answer why not, in particular, to each of these - to Grundtvig - utterly unviable options! The point is - and it is a point which needs careful explanation to any English readership - that through much, perhaps most, of his Anglo-Saxon work, as through so many of his undertakings, Grundtvig is seeking not the status of an academic contributing to international scholarship but the role of prophet and teacher of folkelighed and the folkeaand among the latter-day custodians of the spirit of the ancient North, the Danish people. Folkelighed, I'm told by the editors of the Haandbog i N.F.S. Grundtvigs Skrifter, is a word coined by Grundtvig himself: »Det betyder ikke blot det populære, det demokratiske, eller det nationale. Det betyder et Folks bevidste Fællesskab om sine historiske og aandelige Værdier; og Folkeaanden er den samlende Kraft. $\ll^{24}$ Grundtvig is finding in and through Anglo-Saxondom historical and spiritual values which his historical perspectives allow him to assign to 
the Danes. He is appropriating Anglo-Saxondom into the cultural resources of Denmark. Though this field itself is familiar enough, there are still things to be discovered and said here, I think, in fuller and more detailed awareness of the context of Grundtvig's relationship - his developing relationship - with Anglo-Saxondom. ${ }^{25}$ And they are things which, I say again, require of modern Grundtvig-apologists as much careful mediation to an English-speaking readership in the one direction as they do to a Danish readership in the other.

In this context, obviously enough, belong Grandtvig's paraphrases and his dedicatory poems associated with both editions of Bjowulfs Drape $(1820,1865)$, with Phoenix-Fuglen (1840) and with Beowulfes Beorh (1861) which are composed partly in Old English. Certainly these have been noted and in limited degree discussed, but I am sure there is still a fair amount of really rather interesting work to be done on them. They are not mere jeux d'esprit, not mere witty exercises in the rather outmoded literary genre of pastiche. ${ }^{26}$ There is not a phrase in them which does not have its polemical motivation. And again, while the issues of this polemical content are familiar ones in themselves universal history, mainline Grundtvigian theological ideas, contemporary political issues, folkelighed in its many diverse forms including the ideal of a folkelig education from the nursery upwards - my own preliminary explorations have shown that Grundtvig is deliberately adding an extra dimension to these ideas by articulating them in phrases lifted from significant Anglo-Saxon contexts, in such a way that something of the context still attaches to the reference, and enhances its polemical signification. So here too is scope for further exploration and exposition.

I now move hastily to the work Grandtvig did which never came to publication. The work that was noticed long since by earlier AngloSaxon scholars was his planned edition of the Exeter Book: this I have myself now analysed and recently published. ${ }^{27}$ In retrospect, I am left half aghast at the huge sacrifice of time and intellectual effort this work represents (I do not say 'waste' but 'sacrifice'). Even so, I conclude that it was far from being as near completion as Grundtvig allowed people to think in $1840 .{ }^{28}$ But it is an absorbingly interesting document in the early history of the establishment of modern Anglo-Saxon scholarship, for this reason deserving to be noted henceforth in the record of the reception of Anglo-Saxon as an academic study in the nineteenth century. Grundtvig did not cease work on this material when his English 
rival Thorpe achieved the publication of the editio princeps in $1842 .{ }^{29}$ It fairly obviously continued to serve his own interests and purposes even when the hope of publishing it as an edition of the texts receded beyond hope. And it proves indeed to be the case that there is material in this archive relevant to the study of other aspects of Grundtvig notably his wide-ranging philological interests (so interestingly opened up by Helge Toldberg ${ }^{30}$ ), and - what is for me a particularly important and absorbing area in the context of nineteenth-century Romanticism and the issue of artistic self-identity - the construction of his own linguistic and formulaic resources as a poet.

Concerning this last matter: I have also made token gestures towards demonstrating that the diction, idiom and ideas of certain Anglo-Saxon poems have been assimilated into Grundtvig's eclectic creative resources and reappear in his own poetry; and I have suggested that the same may prove true of his treaty with the distinctive diction and idiom of Anglo-Saxon prose, particularly of the homiletic prose. On these possibilities I should like to say clearly that I have never expected to be able to amaze and embarrass Danish literary scholarship (as Grundtvig delighted in embarrassing English literary scholarship!) by demonstrating that a hitherto unrecognised Anglo-Saxon source lies behind every tenth line of Grundtvig's poetic or homiletic corpus. Methodologically speaking, we are bound to be extremely circumspect here. Apart from the extraordinarily eclectic habit of Grundtvig's mind, and his readiness to conjoin what on the face of things seem incongruous elements (the basis of my article "Stridige Stykker snild jeg forbandt... $\ll^{31}$ ), I might note just one other far-reaching qualification. The language of the Anglo-Saxons, aspects of their preferred poetic form and poetic idiom, and aspects of their culture as a whole, share with early Norse (particularly Icelandic) culture a common inheritance from the pan-Germanic past. Grundtvig was deeply versed in Old Icelandic language and literature, well before he immersed himself in AngloSaxon. He was also committed to working in mythic symbols which by definition have about them a certain universality and ubiquitousness of both place and time. Therefore, a certain commensurate burden of proof lies upon Anglo-Saxonists who would claim that such and such a feature of Grundtvig's utterance is categorically owed to Anglo-Saxon influence and to no other. This is work with some daunting aspects to it, work which is also bound to be controversial - because very rarely in such a field can we find ourselves dealing with simplex certainties and 
absolutes. But I am quite certain that substantial contributions are waiting to be made through this approach to the study of Grundtvig's poetic and prose diction and the images these articulate. The appreciation of Grundtvig's unique resourcefulness can only be enhanced by careful and painstaking critical enquiry in this area; and it is therefore good to know that such work is now beginning to taking root among younger researchers here in Denmark.

There is another major body of material in the archives, to which I have drawn fresh attention and which I myself am currently exploring further. This is Grundtvig's work on the collection of Anglo-Saxon poetry traditionally attributed to Cædmon, contained in Oxford Bodleian Library MS Junius $11 .^{32}$ The folder of material on this collection comprises the Old English texts in transcription, materials for a paraphrase in the style of his published paraphrase of Beowulf, and the beginnings of an introductory poem which has an interesting theological slant to it. ${ }^{33}$ Though the scholarly world has barely taken note of this archive, as far as I know, it must have represented for Grundtvig at least as important an ambition as his aims for the Exeter Book - and it must have been at least as disappointing and frustrating for him when, as early as 1832, Benjamin Thorpe became the author of the editio princeps. ${ }^{34}$ But as also in the case of the Exeter Book transcriptions Grundtvig continued working on his transcriptions of Junius 11 and there is promise here of research-gains similar to those offered by the Exeter Book papers. There may have been a prolonged period when both these Anglo-Saxon projects were, as it were, open files on Grundtvig's desk, over the period when he was fundamentally reworking Nordens Mythologi for its second edition, and compiling the Sangvark. I see some significance in this fact, to which I shall return for a moment very shortly.

I have argued the possibility that Grundtvig formed an important part of his self-identity as a poet and even as a prophet through his reaction to his encounter with the figure of Cædmon, the first Christian poet of the English language - Anglo-Saxon England's Christian Brage, as it were; and Anglo-Saxondom's heir to the harp of David the psalmist. ${ }^{35}$ Professor A.M. Allchin has taken up my suggestion in his recent book - and sounds as uncertain as I am about its favourable reception among those who know best about Grundtvig: »To Danish readers of this book it will probably seem simply perverse that in a chapter on Grundtvig in the 1830 s so much has been said about his 
translations from ancient languages and his inner discovery of himself as called to be a poet in the tradition of David and Cædmon. ${ }^{36}$ Still he feels entitled to go ahead and argue that Grundtvig's »appreciative appropriation of the Anglo-Saxon past « $^{37}$ actually fits logically and revealingly into the pattern of Grundtvig's development over the important decade of the 1830s. And in his most recent article Professor Allchin has expressed more categorically than I myself expressed what I was trying to say in my discussion of Grundtvig's handling of Creation theology and Redemption theology in his representations of Cædmon. ${ }^{38}$ The influence of Irenaeus and the liturgical translations from Greek and Latin in the 1820s and 1830s, he writes, is widely recognized: »But already before that it seems to me that there were other influences at work. Perhaps Grundtvig's first attraction to the poetry of the AngloSaxons was not only literal and historical, but also seriously theological. This is a line of thought which I believe deserves further exploration. $\aleph^{39}$

I feel, then, that this Cædmon-topic is a particularly important development beyond the earlier Beowulf and Sangvark-polarised account of Grundtvig and Anglo-Saxondom, which I very much hope will prove to hold.

One other way ahead, which I can only very cursorily mention here, is the examination of Grundtvig as reflected, so to speak, in the mirror of his followers.

As early as 1835, Ludwig Christian Müller, tutor to H.C. Andersen, Søren Kierkegaard and Grundtvig's sons, talented linguist in Hebrew, Syrian, Icelandic, produced a small anthology of Anglo-Saxon texts with, incidentally, Latin editorial apparatus. ${ }^{40}$ In the introduction to this book he gratefully acknowledges Grundtvig's advice and direct help including giving Müller access to his transcriptions of the Exeter Book. ${ }^{41}$ This publication was evidently the first fruit of Grundtvig's cultivation of Anglo-Saxondom within his circle. But progress in formal terms was slow. The Grundtvigians had little access to University positions. In this respect, Professor George Stephens was an extremely important friend and collaborator with Grundtvig; and as such certainly deserves some fresh consideration in this context of Grundtvig research. ${ }^{42}$

But with Frederik Hammerich (1809-77), theologian and historian, the Grundtvig circle had a kind of breakthrough. ${ }^{43}$ Certainly Hammerich saw his own appointment as professor in Church History (1859) as bucking a trend in the rule of the establishment over University 
appointments. ${ }^{44}$ In 1873 the University published a series of Hammerich's lectures under the title: De episk-kristelige oldkvad hos de gotiske folk. ${ }^{45}$

The series opens with a study of Anglo-Saxon poetry, with separate sections dedicated to Cædmon and to Cynewulf. Writing of this undertaking, Hammerich says in his memoirs (in terminology which characterises the period and the man): »I mit universitetsprogram 'de episke-kristelige oldkvad hos de gotiske folk' er jeg kommen ind på æmner, som levende tiltrak mig alt i de yngre dage. Min vej havde siden ført mig andensteds hen, men da jeg nu på ny ledtes til dem, var det, som vandrede jeg i en af oldtidens storskove; disse toner lød i mit øre som gamle, halvglæmte melodier og tryllede mig min og hele vor folkeæts ungdomsdrømme tilbage. Her slyngede manddom og kristendom, det mytiske og det kristelige, det historiske, det sproglige og det digterske sig sammen på en måde, som netop ligger for mig; det blev da det af mine arbejder, hvor jeg måske mest har været med. « $^{46}$

In a passage which illumines both the post-Grundtvigian author and the post-Grundtvigian readership of his work, Hammerich quotes compliments he has received for it: »Jeg kan ikke nægte mig den glæde at meddele et par ord om det $\mathrm{i}$ et brev fra Birkedal. "Tak for Deres prægtige gave, jeg har forlystet mig tusindfold i skildringerne af Goternes livsanskuelse. Deres ledsagende betragtninger er fortræffelige og dybtgående, og Deres gengivelse af versene finder jeg klingende af malm og harpestrenge. Og det dufter og funkler en i møde! Det er ikke bestilt arbejde, men ånden hos Goterne har fundet og mødt ånden hos Dem. Den mandige Kristendom! Ja, det kan jeg forstå, og det har vakt genklang i mit lille hjerte.« Også fra professor Jensen på Oringe fik jeg en varm tak, hans yndlingsdigt var det angelsaksiske om sømanden. « $^{47}$ This last is, of course, the poem now called The Seafarer from the Exeter Book - a poem which I have elsewhere suggested may well have influenced Grundtvig's last poem, Gammel nok er nu jeg blevet. ${ }^{48}$

In Hammerich's assessment, the Anglo-Saxons have now been firmly incorporated in the Danish (Grundtvigian) view of the historical folkeliv, the Christian tradition of Norden, the received pattern of history: »Hvor Angelsakserne oversés, forstår man hverken kristendommens eller kulturens vandring gennem Evropa, hverken Goternes eller Romanernes historie. ${ }^{49}$ This view of history, laid out in Grundtvig's Christenhedens Syvstjerne, is familiar. But Hammerich is concerned not only with the Anglo-Saxon place in the broad sweep of history; he is 
also interested in the details, the artefacts, of Anglo-Saxon culture and particularly in Anglo-Saxon literature; and, as we have already begun to hear, this literature clearly offered Hammerich a means of expressing his own personal andsliv. His testimony is in fact a valuable document for the study of that rather difficult subject, the actual way in which poetry particularly religious poetry, and above all early medieval religious poetry - works upon the individual recipient: a very interesting subject indeed in the broad context of Grundtvig's reception of Anglo-Saxon literature, even if one which is prone to getting bogged down in subjectivity on both sides, the recipient's and the observer's.

Hammerich gives much space in his lecture to The Dream of the Rood, and reproduces there George Stephens's fine engraving of the Ruthwell Cross. The Dream of the Rood is an outstanding poem by any standards, one which displays a very different area of Anglo-Saxon spirituality from that expressed in the poetry of Junius 11 . It is deeply affective, mystical and penitential poetry, thoroughly characterised by the oldkirkelig in idiom, thought and spirit, a spiritual exercise in apprehending the power of the Holy Rood to call back a guilt-oppressed soul to trust and joy in the redemption achieved for all by Christ's great struggle upon the Cross.

There is not time now to do justice to Hammerich's work and his own perspectives upon the landscape created by Grundtvig. It would be foolish to speak of him as though he were not his own man. Disciple of Grundtvig though he gladly professed himself throughout his life to be, he was, as the Dansk Biografisk Leksikon says, »en selvstændig Discipel « - an independent disciple. ${ }^{50}$ One quotation will have to serve here to intimate where Hammerich stood, as the selvstandig Discipel of Grundtvig.

Hammerich is speaking of mythology. The myths of heathendom, he says, though they share what he calls »den vidunderlige romantik « that wonderful romanticism - with the great Christian visions, cannot be given the status of Christian visions such as those of John (in The Apocalypse) concerning the last things - or, we might add (on Hammerich's own promptings, and on a more modest scale) such as those of the poets of Rood or the Christ-poems in the Exeter Book. Of such visionaries he says: »Det går med de sidste ting i det hele som med de første, kun i syner kan de åbne sig for os, helligt dæmrende syner, hvori virkelighed, historiske minder eller anelser, tro, digtning, tanke ere i hinanden og gennemtindre hinanden i livets enhed. Derfor har vantroen 
også uden videre villet stille dem jævnsides med hedenskabets myter, med hvilke de har den vidunderlige romantik tilfælles. Fuldstændigt blind er den naturligvis for grundforskellen mellem Guds sandhedsånd og en drømmende verdensånd, selv hvor der drømmes så stort som i vølvens varsler, da hun dukkede sit hoved op over tidernes hav. $\ll^{51}$

This last point brings us, finally, back to Thaning and to the formidable monument called Nordens Mythologi. ${ }^{52}$ I mean to say little about this work on this occasion, partly because I am only now bracing myself to address what has in the past seemed to me a bit of a problem. Grundtvig returns from three visits to England, supposedly full of impressions of the Anglo-Saxon manuscripts and bearing transcriptions of the Exeter Book; as Thaning (among others) so powerfully argues, he then settles down to write a key document in his ideological testament concerning Nordens Aand, the spirit of the North... and it might seem, at first sight, as though, in terms of his focus in this work, in terms of the status he gives the testimony of Edda and Saga, little has changed as a consequence of the encounters with the Anglo-Saxon manuscripts.

This thoroughgoing prioritisation of Old Norse myth and legend as the primary source of symbol and metaphor for the analysis and discussion of Nordens Aand in history and in contemporary life seems bound to marginalise the contents of the Anglo-Saxon manuscripts. Most surviving Anglo-Saxon poetry and the bulk of Anglo-Saxon prose, after all, express through topic and through idiom the conscious participation of the English Church and people in the orthodoxies of western European Christendom. Except in Beowulf, there is very little reference indeed in Anglo-Saxon poetry to northern myth and legend, and there is no certain surviving remnant of an Anglo-Saxon saga genre comparable to the Icelandic. From his first edition to his second, therefore, Grundtvig has adhered unswervingly to Norse myth and legend as the essential stuff of his manifesto concerning the Nordic past, present and future. That, at least from the self-concerned viewpoint of an Anglo-Saxonist, is one problematical aspect of Nordens Mythologi, to which I will return shortly.

»Dialogue across the North Sea « was the subtitle of the conference session in which this paper was originally given. Since Grundtvig first addressed the English antiquaries about the Anglo-Saxon manuscripts, there have been various such Danish-English dialogues to mutual profit, including those sponsored over the last ten years by the Centre. But here with Nordens Mythologi there is, as I presently see it, a real conflict of 
cultural allegiances still awaiting resolution. On English 'classical' culture, Grundtvig expresses his verdict uncompromisingly in Nordens Mythologi: "Jeg paastaaer da først, at der er intet Land, hvor den Romersk-Italienske Videnskabelighed er saa grundfæstet som i Engeland...jeg paastaaer ogsaa, den er ikke værd at redde, thi den staaer fiendtlig mod alt virkeligt Liv i Aandens Verden, og er derfor saa langt fra at lede til nogen Forklaring af Livet og Aanden, at den tvertimod alle sin Dage...har ledt til Folke-D $\varnothing d$ og Aands-Fornægtelse. ${ }^{53}$ His remedy is loftily and often patronisingly to invite the English into a world and a world-view they have seldom shown the slightest serious inclination towards sharing. In so far as Grundtvig hoped that this body of myth and legend might become for the English too a universal Northern stock of narrative and imagery for the cultivation and expression of a universal Northern Spirit, time has proved that he backed a loser; and accordingly those who wish to mediate Grundtvig to the English-speaking world face a special problem in respect of the polemic of this particular work. Debate on this issue would be most welcome.

For present purposes, I will venture only one, double-pronged observation about Nordens Mythologi as evidence that Grundtvig has after all absorbed some significant ideas from his encounter with the AngloSaxon manuscripts, which he now desires to fit into his definitive portrait of Nordens Kampeaand - the battling spirit of the North.

First, I note that the Mythologi is in the end almost as much about the skjalde - the poets - and their crucial role as transmitters and arbiters as it is about the stories they transmitted. And since the author portrays himself in the introductory poem as a skjald, we understand that Grundtvig identifies himself as standing in the tradition of the skalds of old. This, of course, is exactly what I was led to conclude in the Cædmon area as well. ${ }^{54}$ So I am disposed to argue that it is under both of these personae - functioning, that is, both as the latter-day successor of Norne-Giæst or even of Brage, and as the latter-day successor of Cædmon or even of David - that Grundtvig addresses two of his great undertakings of the 1830s; namely, the revised and definitive interpretation of the mythology of the North (1832) and the compilation of a Sang-Vark til den Danske Kirke (1837), in the decade following his English visits.

The second and related part of my observation is that Grundtvig does in fact conspicuously honour Anglo-Saxon poetry - poetry from 'his' Exeter Book, in fact, copied in England in 1830 or 1831 - in the 
exposition of Nordens Mythologi in 1832. Indeed, he does no less than give the very last word in this epic survey of Norse mythology to AngloSaxon poetry. In his final chapter, on Norne-Giæst - a figure who is »kiendelig paa alle Steder, hvor der er Øie for Nordens Aand ${ }^{55}$ Grundtvig marvels at the supremely poetic idea embodied in this mythic persona - »et Indfald, saa poetisk som det, at lade Aanden med Harpen giennemvandre Heden-Old og at lade hans Livs-Lys brænde ned i Piben hos Olav Tryggesön. ${ }^{56}$ When he asks, rhetorically, where this wonderful idea originated, then (he answers himself): »maa jeg atter her giætte paa en Angel-Sachser « and he thereupon turns to discussion of the poem Widsith. He doesn't like the poem as such - »jeg finder den tvertimod temmelig smaglöst, og i det hele kiendelig mat « but the idea running through the poem - »saa er den høipoetisk. $\ll^{57}$ The poet-figure within the poem, who wanders with his harp through »alle de Folk under Solen, der havde Poesi «, ${ }^{58}$ is like »Falken, som fra Hvile-Höien kaster Blikket tilbage paa sin stolte Bane, og skiöndt vi nok see, at Sangeren har Guldet bag Öret, kan vi dog ikke nægte, han har Ret, naar han slutter:

Det har jeg lart,

Paa lange Reiser,

At Drot bruges bedst

Sin Dag i Glands,

Naar dem han marker,

Som muntre gaae,

Giennem Hald og Hytte,

Med Harpe-Slag,

Ei gnider paa Guld,

Men gavmild saaer

Hvad op kan voxe

Til Ares-Höst!

Er Livet svundet,

Og Lyset slukt,

I Sky sig svinger,

Som Fugl i Skov,

Paa Tone-Vinger,

Hans gode Lov! 
See, det var netop, som vi veed, den Verdens-Klogskab, Konger og Helte i gamle Nord beflittede dem paa, og hvem kan nægte, at AngelSachseren fik Ret! « ${ }^{59}$

And so, after this poetic paraphrase of the closing lines of the Anglo-Saxon poem Widsith, Grundtvig moves into his final stirring peroration upon the near-holy obligation resting upon us in this latter day to learn to treasure »Levningen af Skjalde-Livet « - the legacy of the bardic life - and to listen again to the backward memories and forward visions of skjaldene - the poets. Though Grundtvig chooses here, in the context of this particular thesis, to take the poet-figure in Widsith as his archetypal poet, rather than Cædmon whom he had already made his archetypal poet in the context of another, more explicitly Christianreligious thesis, I believe it would not be difficult to find common language and common concepts between his separate accounts of these two poets. And it would be no more difficult to show that each, in their respective compartments within Grundtvig's total understanding of Folke-Livet and Folke-Aand, Poesi and Skjaldlivet, and of his own skjald-identity, in relation to the great role-models from the northern heritage, each was as important to him as the other.

How typical, then, of Grundtvig, and how revealing it is, as I believe, of the contribution of the encounter with the Anglo-Saxon manuscripts to his definition of his own poetic identity, that we find we can associate two of his great and decisive preoccupations of this crucial decade of his life - the second edition of Nordens Mythologi and the Sangvark for den danske Kirke - with these two poets - Anglo-Saxon poets - archetypes, as he projects them - the legendary and the historical, the secular and the religious, the legend-laden and the Scripture-laden, the informed and the inspired, the repository of the kampeaand and the vessel of the Holy Spirit, the successor of Brage and the successor of David - Widsith and Cædmon.

\section{Notes}

1 Preparation of this paper was largely completed in the Grundtvig-Bibliotek in Vartov, Copenhagen. I wish to record my thanks to Kirkeligt Samfund for accommodating me as a guest at Vartov, Hans and Kirsten Grishauge and their colleagues there for such warm hospitality, and the staff of the Grundtvig-Bibliotek for their ready help. I owe a special debt of gratitude once again to N. F. S. Grundtvigs Fond for generous financial assistance which made possible two extremely valuable research visits to Aarhus and Copenhagen in 1998. 
2 Helweg, F., »Om Grundtvig og Høyen« in Nordisk Månedsskrift for folkelig og kristelig Oplysning udgivet af L. Helveg, Fr. Ingier, Ge. Vilh. Lyng, L. Schrøderog L. Ingier, Første Halvårgang 1873 (Odense 1873), pp. 404-5: »...det er årene imellem 30 og 40, som iøvrigt var en overgangstid i vort folkeliv ikke mindre end i Grundtvigs personlige liv. I skrifterne fra årene $30 \mathrm{er} \mathrm{det}$, at han fremlægger sit livssyn, således at han selv henholdt sig dertil og vi ligeså kunne (og bör) henvise dertil; disse skrifter vare mytologiens anden udgave og verdenshistorien...Men derved kommer ydermere en fremmed indflydelse i betragtningen, for så vidt det som påvirker åndeligt kan kaldes fremmed, og navnlig Englands forhold til Norden tör betegnes på den måde. I de næunte år falder Grundtvigs levende berøring med England, nærmest hidført ved en skrinlagt fortid (det angelsaksiske), men som fik mindst lige så meget at betyde gennem det samtidige og samlevende.« [...it is the years between ' 30 and ' 40 , which incidentally was a time of transition in our folkeliv no less than in Grundtvig's personal life. It is in the writings from the Thirties that he sets out his philosophy of life, according as he for his part committed himself to it and we similarly were able (and duty bound) to refer to it: these writings were the second edition of the Mythology and the World History...But along with this there further comes into consideration a foreign influence - insofar as that which works its effect through the spirit (and especially may England's relationship to the North be characterised in this way) can be called foreign. In the years mentioned occurs Grundtvig's real-life contact with England where he was drawn rather by an abandoned past (the Anglo-Saxon) but which came to mean at least as much through the contemporary and the coexistent].

Borup, E.J. and Schrøder, F., Haandbog i N.F.S. Grundtvigs Skrifter. II: Folkelige Grundtanker (Copenhagen, 1930), p. xiii: »they derive their importance not so much from his studies in the Anglo-Saxon manuscripts, where it is the English themselves who harvest the fruit, as from the fruitful promptings which life in England gives him in manifold ways.«

See below, notes 6,7 .

Grundtvig, N.F.S., Sang-Vark til den Danske Kirke (Copenhagen, 1837).

Thaning, K., »Grundtvig, an Introduction « in Grundtvig Studier 1973, pp. 68-84. The quotations cited are from pp. 72-75.

In his earlier, major study Menneske først - Grundtvigs opgфr med sig selv (Copenhagen, 1963), Thaning gives a much more extensive and analytic account of the impact of the England-visits upon Grundtvig's development in the 1830s, particularly upon his drafting of the second edition of his Nordens Mythologi (1832). But there too the experiences which Thaning finds significant he defines only in broad terms: »Den sidste Englandsrejse har afklaret det gamle Nordens betydning for den historiske erkendelse, der for Grundtvig er ét med selverkendelse... «[Thaning, op. cit., vol. 1, p. 110: »The last England-visit has clarified the significance of the ancient North for that historical realisation which for Grundtvig is one with self-realisation «]. 
Hammerich, F., Min Sidste Samtale med Grundtvig in Danske Kirketidende. Udgivet af $N$. Lindberg. 1872 (Copenhagen, 1872), cols. 675-676; of which an excerpt is in Johansen, S., and Høirup, H., Grundtvig's Erindringer og Erindringer om Grundtvig (Copenhagen, 1948), pp. 262-263 . A shorter account is given by Hammerich in Et Levnedsl $b$ af Fr. Hammerich. Udgivet af Angul Hammerich. (Copenhagen, 1882), Anden Del, p. 216.

Helge Toldberg, Grundtvig som Filolog (Teologiske Studier Nr. 8 Dansk Teologisk Tidsskrıft. II Afd.; Copenhagen, 1946), p. 40: »Those books which Grundtvig either owned or borrowed had a far greater influence upon his authorship than is conventionally acknowledged «; and »that there developed with the years a more and more precise connection between Grundtvig's reading and his various enterprises, eminently so in the philological field.«

Research on the acquisition dates, destinations and present locations of Grundtvig's books has been undertaken by, among others, Helge Toldberg and K.E. Bugge, but I have not complicated the present account by involving this work. Information is taken from Fortegnelse over den af N.F.S. Grundtvig efterladte Bogsamling, som bortsalges ved offentlig Auction i Klcedeboderne Nr. 38 Mandagen den 29. Sept. $1873 \mathrm{Kl}$. 10. (Copenhagen, 1873), pp. 148-150. Numbers in square brackets indicate the item number in the Fortegnelse. Some additional titles of interest are: S. Fox's edition (1835) of King Alfred's Anglo-Saxon Version of the Metres of Boethius [4019] and Menologium, or the poetical calendar of the Anglo-Saxons (1830) [4026]; J. Bosworth's A Dictionary of the Anglo-Saxon Language (1838) [2456]; An edition of Ælfric's Grammar and the Old English word-lists attributed to him, in T. Phillips, Fragment of AElfric's Grammar. Alfric's Glossary and a poem on the soul and body (1838) [3991]; Sharon Turner's three-volume The History of the Anglo-Saxons, I-III (1840) [7638-40]; and later Pauli's The Life of Alfred the Great, translated from the German by B. Thorpe (1853) [7641]; The Anglo-Saxon Version of the life of St. Guthlach, written by Felix of Crowland (1848), edited by C.W. Goodwin [4024]; J.J.A. Worsaae, Minder om de Danske og Nordmandene i England, Skotland og Irland (1851) [5212] and Den danske Erobring af England og Nordmandiet (1863) [5213]; There are also, of course, editions and translations of Beowulf and other Anglo-Saxon poetry which were emerging throughout Grundtvig's lifetime. These include: J.M. Kemble, Beowulf, The Traveller's Song and The Battle of Finnesburh. 2nd edition (1835) [4005] and A translation of the Anglo-Saxon Poem of Beowulf (1837) [4014]; A.D. Wackerbarth, Beowulf. Translated into English Verse (1849) [4015]; B.Thorpe Beowulf, The Scôp or Gleeman's Tale, and The Fight at Finnesburg (1855) [4007]; $\mathrm{H}$. Leo, Bëówulf, nach seinem inhalte und nach seinen histor. u. mytholog. bezeihungen betrachtet (1839) [4016]; L. Ettmüller, Beowulf. Aus dem Angelsächs. in das Neuhochdeutsche stabreimend übers. v. L. Ettmüller (1840) [4013]; C.W.M. Grein, Bibliothek der Angelsächsischen Poesie. Herausgegeben von C.W.M. Grein. I-IV (1857-64) [3984 - 85]; C.W.M. Grein, Dichtungen der Angelsachsen stabreimend übersetzt. I - II. (1857 - 59) [3986]; Grein, C.W.M., Beovulfnebst den Fragmenten Finnsburh und Valdere, herausgegeben von C.W.M. Grein. Cassel, (1867) [4009]; M. Heyne, Beóvulf. Mit Glossar. 2nd edition (1868) [4010]; L.G. Nilsson, Några fornengelska, andeliga qväden på grundspråket (1857) [3983] and 
Judith, fragment af ett forneng. quäde, m. Svensk övers. af L.G. Nilsson (1858) [4025].

11 Thorpe, B.,Cadmon's Metrical Paraphrase of the Holy Scripture. London, 1832. [4020]. Another copy of the same [4021].

Bouterwek, K.W., Des Angelsachsen Biblische Dichtungen. Herausgegeben von K. W. Bouterwek. 1 Abthl. [Cædmon's Paraphrases] (1849) [4022].

13 Thorpe, B., Libri Psalmorum versio antiqua Lat. cum Paraphrasi Anglosaxonica (1835). [4029].

14 Kemble, J.M., The Poetry of the Codex Vercellensis with an English translation (1843). [3972].

15 Thorpe, B., The Sermones catholici of Alfric (1844-46). [3992-93].

16 Norman, H.W., The Anglo-Saxon Version of the Hexameron of St. Basil and of St. Basil's Admonitio ad filium spiritualem (2nd ed., 1849) [4003]. In this connection it is intriguing that Professor Lossky likens Grundtvig as theologian, hymn-writer, liturgist and poet to two of the great Fathers of the Church, St Ambrose - and St Basil; Lossky, N.V., Afterword, in Allchin, A.M., N. F. S. Grundtvig. An Introduction to his Life and Work (Aarhus and London, 1997), p. 317.

17 Stephens, G., The King of the Birds, or the Lay of the Phoenix, translated into the metre and alliteration of the original by G. Stephens (1844) [4028].

Stephens, G., Two Leaves of King Walderes Lay. Published by G. Stephens (1860) [4032]. A gift from the author.

Stephens, G., The old-northern runic monuments (1866-68) [5102-3].

Allchin, A.M., N.F.S. Grundtvig. An Introduction to his Life and Work (Aarhus and London, 1997), pp. 287 following.

21 Grundtvig, N.F.S., Bjowulfs Drape. Af Angel-Saxisk paa Danske Riim ved N.F.S. Grundtvig (Copenhagen, 1820); and (2nd edition) Bjovulvs-Drapen, et Høinordisk Heltedigt, fra Anguls-Tungen fordansket af Nik. Fred. Sev. Grundtvig. Anden forbedrede Udgave (Copenhagen, 1865).

This contribution is largely a matter of record: e.g., J. Earle, in The Deeds of Beowulf (1892), pp. xv ff., xii ff, and xxxvi ff., who was probably the first English Anglo-Saxonist to acknowledge in print Grundtvig's role in the formative years of Anglo-Saxon scholarship ; R.W. Chambers, The Exeter Book of Old English Poetry (London, 1933), pp. 33-34; various editions using or noting Grundtvig's emendations and annotations (notably on Higelac as historical figure); and the work of Kemp Malone, Eric Stanley, Andreas Haarder and Flemming Lundgreen-Nielsen, 
among others.

Grundtvig, N.F.S., Phoenix-Fuglen, et Angelsachsisk Kvad, udgivet med Fordanskning af N.F.S. Grundtvig (Copenhagen, 1840).

Borup, E.J., Schrøder, F., Haandbog i N.F.S. Grundtvigs Skrifter. II: Folkelige Grundtanker (Copenhagen, 1930), p. x: »It means not only the popular, the democratic, or the national. It means a folk's conscious solidarity over its historical and spiritual values; and the folk-spirit is the unifying force.«

It seems to me interestingly symptomatic of Grundtvig's developing relationship with Anglo-Saxondom, that while his first Danish paraphrase of Beowulf is subtitled Et Gothisk Helte-Digt fra forrige Aar-Tusinde af Angel-Saxisk paa Danske Riim [A Gothic heroic poem from the previous millennium, in Danish verse from the Anglo-Saxon] the second edition is subtitled, with a redirected polemical intent, Et Høinordisk Heltedigt, fra Anguls-Tungen fordansket [A High-Nordic heroic poem rendered into Danish from Angul's-speech (Angul, eponymous founder of the English, being legendary brother of Dan, eponymous founder of the Danes)].

Though I have commented a little drily in the past (»Grundtvig, Anglo-Saxon Literature, and 'Ordets Kamp til Seier' " in Grundtvig Studier 1989-90, note 13, p. 238) upon Grundtvig's pastiche compositions in direct comparison with the poetics of the sources, this does not diminish my appreciation of these pastiches in their own terms, as a complex, subtle and creative mode of polemic.

Bradley, S.A.J., N.F.S. Grundtvig's Transcriptions of the Exeter Book... An Analysis, Skrifter udgivet af Grundtvig-Selskabet 28 (Copenhagen, 1998).

Grundtvig, N.F.S., Phenix-Fuglen. Et Angelsachsisk Kvad (Copenhagen, 1840), Fortale, p. 13: see also Bradley, Transcriptions (as in note 27), p. 10.

Thorpe, B., Codex Exoniensis (London, 1842).

Toldberg, H., Grundtvig som Filolog, Teologiske Studier Nr. 8. Dansk Teologisk Tidsskrift. II. Afd. (Copenhagen, 1946).

Bradley, S.A.J.,»'Stridige Stykker snild jeg forbandt' - Grundtvig's creative synthesis of Anglo-Saxon sources« in Grundtvig Studier 1996, pp. 97-127.

Fascicle 320, items 1-3; described in the Registrant over N.F.S. Grundtvigs Papirer, vol. XV (Copenhagen, 1959). The dating and chronology of Grundtvig's work here is not yet completely settled but internal criteria suggest that some of it predates his first visit to England in 1829, while annotations based on Thorpe's edition must have been made after 1832. Grundtvig discussed the figure of Cædmon (in Bede's Ecclesiastical History) and alluded to the poetry traditionally ascribed to Cædmon in his poem Ragna-Roke (et danske AEmter) published in 
Danne-Virke: Et Tids-Skrift, vol. III (Copenhagen, 1817); see further my article, »Stridige Stykker...« (as in note 31), pp. 104 following.

See my article »Stridige Stykker...« (as in note 31), especially pp. 112-113 and 116 -117 .

Thorpe, B.,Cadmon's Metrical Paraphrase of the Holy Scripture. London, 1832. Grundtvig owned two copies, nos. 4020 and 4021 in Fortegnelse over den af N.F.S. Grundtvig efterladte Bogsamling, som bortsalges ved offentlig Auction $i$ Kladeboderne Nr. 38 Mandagen den 29. Sept. 1873 Kl. 10. (Kjøbenhavn. E.C. Løsers Bog- og Nodetrykkeri. 1873.).

Here we might usefully recall Grundtvig's interest in Thorpe's edition of the Anglo-Saxon poetic paraphrases of the Psalms of David. This work was not published until long after Grundtvig had first encountered and responded to the persona of Cædmon and made the link with David and perhaps with himself; but potentially it is a sign of Grundtvig's abiding interest in this seminal figure in his conceptualising of the early Church in the North and its relevance to the cultural present in Denmark and the North.

Allchin, A.M., op. cit. (note 20), p. 60.

Allchin, A.M., op. cit. (note 20), p. 55.

Allchin, A.M., »The Holy Spirit in the Teaching of N. F. S. Grundtvig «, in Grundtvig Studier 1998, pp. 175-189.

Allchin, A.M., op. cit. (note 38), p. 187.

Müller, L.C. (1806-51), Collectanea Anglo-Saxonica (Copenhagen, 1835). Müller was a priest with outstanding expertise in Hebrew; also competent in the Syrian language and (with encouragement from Rasmus Rask) in Icelandic; in his earlier years a teacher and private tutor, later resident Kapellan at Ribe Cathedral, parish priest, and principal of Snedsted/Ranum seminarium; was introduced to the Grundtvig household by J.C. Lindberg and became a faithful disciple of Grundtvig in matters both of church and of folkelighed; in a poem to Müller's memory Grundtvig wrote that »faa havde mig saa kær « [few held me in such affection]; at Borchs Kollegium Müller gained high repute and a following, also within the Court, for his fortcellinger of Danish history. Committed to Grundtvigian educational ideology, he was involved in preparatory work on establishment of Rødding Højskole; his historical writings lasted long in popularity. Information from the Dansk Biografisk Leksikon (1939), vol. XVI, pp. 280-282.

Müller, L.C., op. cit. (note 40), pp. IV-V. 
George Stephens (1813-1895); after taking his first degree at University College London settled in Stockholm and became deeply involved in antiquarian, linguistic and folk-study circles, through which he came into contact with Svend Grundtvig; appointed Lektor in English in the University of Copenhagen 1851, acquired citizenship, and in 1855 was nominated Professor, holding the post until retirement in 1893; assiduously pursued own ideas of a 'Scando-English' dialect and of English as a Nordic language, with little support from the rest of the scholarly world; published The Old Northern Runic Monuments (vols. I - II in 1866 - 1868, with supplements in 1884 and 1901) as well as other studies in runic monuments; as a result, came into conflict with Sophus Bugge and others over the integrity of his linguistic understanding and interpretation of particular runes; founded Universitetsjubilæets danske Samfund in order to counter the linguistic school of Rasmus Rask. Information from the Dansk Biografisk Leksikon (1942), vol. XXII, pp. 585-588.

Peter Frederik Adolph Hammerich (1809-1877); under the influence of J.C. Lindberg's religious instruction and Grundtvig's preaching, became early in his life a great admirer of Grundtvig, though later much affected by the German Romantics; through family connections with Sønderjylland remained throughout his life much involved, both polemically and practically, in the pro-Danish cause in the political and military struggles between Denmark and Prussia over Schleswig and Sønderjylland; for a time parish priest near Kolding, but eventually settled in Copenhagen as an academic historian; elected to the Rigsdag; assumed chair as Professor Church History 1859; published various works on Church history, mystical and scholastic theology, and religious poetry of the 'Gothic' peoples; remained a supporter of Grundtvig throughout his life though in later years eloquently and sometimes bitterly disagreed with various developments and failures among the Grundtvigians; his autobiographical memoirs published by his son, Angul Hammerich, 1882. Information from the Dansk Biografisk Leksikon (1936), vol. IX, pp. 31-36.

Hammerich (Copenhagen, 1882), p. 176: (Concerning his appointment as professor, 1859) „Så var det lykkets for mig, hvad der, på grund af klikevæsenet, brast for Grundtvig, Rudelbach og Lindberg, P. Kierkegaard, S. Kierkegaard, F. Fenger, L. Helveg og allersidst for Skat Rørdam. « [So that came to pass for me which, because of cliqueishness, came to nought for Grundtvig ....and finally for Skat Rørdam].

Hammerich, F., Indbydelsesskrift til Kjфbenhavns Universitets Aarsfest til Erindringen om Kirkens Reformation: De episk-kristelige oldkvad hos de gotiske folk (Copenhagen, 1873). That this was a subject embracing concepts dear to Grundtvig's heart can be deduced from Grundtvig's references to the »udvandrede Gother « [emigrant Goths] and their poetry and sagn in Nordens Mythologi; e.g. in the chapter 'Nordens Kæmpe-Aand', p. 174, where he speaks of »den hele SagnKreds, som vi spore i Gothiske, Angel-Sachsiske, Frankiske, Svabiske, Islandske og Danske Mindes-Mærker fra Middel-Alderen « [the whole legendary cycle which we can trace in Gothic, Anglo-Saxon, Frankish, Swabian, Icelandic and Danish memorials from the middle ages]; and in the same chapter (Nordens Mythologi, 
1832; p. 112): »enten Man kalder den Aand Tydsk eller Nordisk, Engelsk, eller Dansk eller Gothisk, er mig nu den ligegyldigste Sag af Verden, naar de blot ikke forvilder Folk, saa de glemme, Talen er bestandig on den Historiske Kampe-Aand, som især Nordens Myther, og Englands Historie efter Folke-Vandringen, giöre kiendelig « [whether one calls this spirit German or Nordic, English or Danish or Gothic, is for me a matter of the greatest indifference in the world, as long only as they do not confuse people so that they forget that they are all the time talking about the historical battling-spirit which particularly the Northern myths and English history after the folk-migration make known].

Hammerich, A., op. cit. (note 44), Anden Del, pp. 226-227: »In my universityprogramme 'The Ancient Christian-Epic Poetry of the Gothic Peoples' I got into topics which had vividly attracted me way back in my younger days. My path had carried me to other places since then but when I was now led to them anew it was as though I wandered in one of the forests of antiquity; these strains sounded in my ear like old half-forgotten melodies and they conjured up for me again the dreams of youth, both mine and our entire nation's. Here intertwined with each other manliness and christianity, the mythic and the christian, the historical, the linguistic and the poetic in a way which just suited me; it therefore became that one of my works in which I was perhaps most engaged. « Hammerich, incidentally, had been initiated into Anglo-Saxon by L.C. Müller: Hammerich, A., op. cit. (note 44), Anden Del, p. 226.

Hammerich, A., op. cit., loc. cit. (note 44): »I cannot deny myself the satisfaction of reporting a couple of words about it in a letter from Birkedal. 'Thanks for your splendid gift. I have found pleasure a thousand times over in the depictions of the Goths' outlook upon life. Your accompanying reflections are excellent and profound, and your rendition of the verses I find redolent of sounding bronze and harp-strings. And the smell and the glimmer of it come and meet one on the way! This is no potboiler: the spirit within the Goths has found and met with the spirit within you. Manly Christianity! Yes, this I can understand, and it has waked a resonance within my little heart.' I also received warm thanks from Professor Jensen from Oringe. His favourite poem was the Anglo-Saxon one about the seafarer.«

Bradley, S.A.J., "'The First New-European Literature': N.F.S. Grundtvig's Reception of Anglo-Saxon Literature « in Allchin, A. M. et al. (eds.), Heritage and Prophecy. Grundtvig and the English-Speaking World (Aarhus and Norwich, 1993), pp. 45-72, especially 65-70.

Hammerich, F., De episk-kristelige oldkvad hos de gotiske folk (Copenhagen, 1873), p. 96: „Where the Anglo-Saxons are overlooked one cannot understand the spread of either Christianity or its culture across Europe, nor the history of either the Gothic peoples or the Romans.« 
Hammerich, A., op. cit. (note 44), Anden Del, pp. 260-61: »It works with the last things, broadly speaking, as with the first: only in visions can they open themselves before us, visions dawning in holiness, wherein reality, historical memories or intuitions, faith, poesy, thoughts are within each other and sparkle through each other within life's oneness. Therefore the unbeliever has also as a matter of course desired to place them on a footing with the myths of heathendom, with which they have a wonderful romanticism in common. Of course the unbeliever is totally blind to the fundamental difference between God's spirit of truth and a dreaming worldly spirit, even when the dreaming is as grand as in the warnings of the seeress [in Völuspá] when she raised up her head above the ocean of the ages. «After the great success of his Episk-kristelige Oldkvad, Hammerich published in 1876 a study of Vølvespaa (Völuspá, »Nordens ældste Digt« - the oldest poem of the North), which the $D B L$ (as note 50 ) calls »den trofaste Scandinavs [i.e. Hammerich's] litterære Testamente - the faithful Scandinavianist's literary testament.

Grundtvig, N.F.S., Nordens Mythologi eller Sindbilled-Sprog historisk-poetisk udviklet og oplyst afNik. Fred. Sev. Grundtvig, Prcest. Anden omarbeidede Udgave (Copenhagen, 1832).

Nordens Mythologi, p. 7: "I suggest first then that there is no country where Roman-Italian learning is so securely established as in England ... But I also suggest that it is not worth saving because it stands hostile to all real life in the world of the spirit, and is therefore so far from leading towards any explanation of Life and of Spirit that it has to the contrary, as long as it has existed, lead to the death of Folkelighed and the denial of Aand."

See note 13 above.

Nordens Mythologi, p. 633: »recognisable in all places where there is an eye for the spirit of the North.«

Nordens Mythologi, p. 633: »an idea so poetic as this, to let the Spirit with the harp wander through antiquity and to let the flame of his life burn down in its holder in the court of Olaf Tryggvason«.

Nordens Mythologi, p. 633: »I must again guess at an Anglo-Saxon «...»I find it to the contrary rather tasteless and in general conspicuously dull«...»that, though, is highly poetic.«

Nordens Mythologi, p. 633: "all those people beneath the sun who possessed poesy.«

Nordens Mythologi, pp. 634 - 35: »...the falcon, which from its lofty resting-place casts its glance backwards upon its proud course; and even though we see that the singer has an eye to his winnings yet we cannot deny that he is right when he concludes: 'This have I learnt on my long travels, that a king best uses his day in glory when he recognises those who cheerfully pass through hall and through hut 
sounding their harp; and gloats not over gold but generously sows what can grow to a harvest of renown! Though life be vanished and light be quenched, in the heavens there soars, like bird in forest on wings of song, his good repute!' Lo! it was, as we know, precisely this worldly wisdom with which the kings and heroes in the ancient North preoccupied themselves; and who can deny that the AngloSaxon was right!« 